\title{
The situation of common wheat rusts in the Southern Cone of America and perspectives for control
}

\author{
Silvia Germán ${ }^{\mathrm{A}}$, Amarilis Barcellos ${ }^{\mathrm{B}}$, Marcia Chaves ${ }^{\mathrm{C}}$, Mohan Kohli ${ }^{\mathrm{D}}$, Pablo Campos ${ }^{\mathrm{E}}$, \\ and Lidia de Viedma ${ }^{F}$ \\ ACorresponding author; INIA La Estanzuela, CC 39173, Colonia, CP 70000, Uruguay. \\ Email: sgerman@inia.org.uy

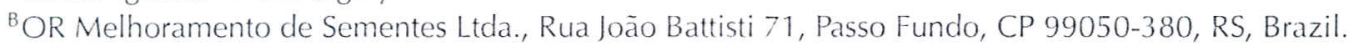 \\ CEMBRAPA Trigo, Rodovia BR 285, km 174, Passo Fundo, CP 99001-970, RS, Brazil. \\ ${ }^{\mathrm{D} C A P E C O}$, Av. Brasilia 840, Asunción, Paraguay. \\ EINTA Bordenave, CC 44, Bordenave, CP 8187, Argentina. \\ FMAG/DIA/CRIA, Ruta VI, km 16, Capital Miranda, Itapúa, Paraguay.
}

\begin{abstract}
Approximately 9 million ha of wheat (Triticum aestivum and T. durum) is sown in the Southern Cone of America (Argentina, Brazil, Chile, Paraguay, and Uruguay). Two rust epidemiological zones separated by the Andean mountain range have been described in the region. Presently, leaf rust (caused by Puccinia triticina) is the most important rust disease of wheat. The utilisation of susceptible or moderately susceptible cultivars in a high proportion of the wheat area allows the pathogen to oversummer across large areas, resulting in early onset of the epidemics. Severe epidemics cause important economic losses if chemical control is not used. The pathogen population is extremely dynamic, leading to transitory resistance in commercial cultivars. Lr34 is commonly present in the regional germplasm, but there is limited knowledge about the presence of other genes conferring resistance in cultivars. Genes $\operatorname{Lr} 28, \operatorname{Lr} 36, \operatorname{Lr} 38, \operatorname{Lr} 41$, and $L r 43$ provide effective resistance in the region. The best strategy for the stabilisation of the pathogen population and resistance is considered to be the use of adult plant resistance conferred by minor additive genes including $\operatorname{Lr} 34$ and Lr 46. Sources of this type of resistance from CIMMYT and the region have been made available to breeding programs in the Southern Cone. Stripe rust ( $P$. strifformis f. sp. tritici) is endemic in Chile where chemical control is required to prevent severe losses in stripe rust susceptible cultivars. Although new virulent races emerge frequently, resistance genes $Y_{r} 5, Y_{r} 8, Y_{r} 10, Y_{r} 15$, and $Y_{r} S p$ are currently effective in Chile. Some important stripe rust epidemics have occurred in Argentina, Brazil, and Uruguay. Avoiding the use of highly susceptible cultivars appears to be an effective strategy to prevent stripe rust epidemic development in this area. There have been no serious stem rust ( $P$. graminis $\mathrm{f}$. sp. tritici) epidemics for over 2 decades; the disease was controlled by resistant cultivars. The most important genes conferring resistance in Southern Cone germplasm at the present time are probably $\mathrm{Sr} 24$ and $\mathrm{Sr} 3 \mathrm{l}$. Other effective genes are $\operatorname{Sr} 22, \operatorname{Sr} 25, \operatorname{Sr} 26, \operatorname{Sr} 32, \operatorname{Sr} 33, \operatorname{Sr} 35, \operatorname{Sr} 39$, and $\operatorname{Sr} 40$. Several stem rust susceptible wheat cultivars have recently been released. The increased cultivation of susceptible cultivars may lead to higher stem rust incidence, increasing the probability of appearance of new virulent races. Since the 1BL.1RS translocation possessing $\operatorname{Sr} 31$ is present in a high proportion of the regional germplasm, the possible introduction of stem rust with Sr3I virulence from Africa is of great concern.
\end{abstract}

Additional keywords: Triticum aestivum, Puccinia triticina, Puccinia striiformis f. sp. tritici, Puccinia graminis f. sp. tritici, pathogen variability, resistance.

\section{Introduction}

Approximately 9 million ha of common (Triticum aesivum) and durum ( $T$. durum) wheat was planted annually in the Southern Cone of America (Argentina, Brazil, Chile, Paraguay, and Uruguay) during 2000-2004 (Table 1). The average yicld was 2.3 tha, resulting in a total annual production of 21 million $t$ of grain (FAOSTAT 2006). Durum wheats are sown only in Argentina and Chile and represent a low percentage of the production. Argentina, where an average 6.18 million ha/year were planted during 2000-2004, is the biggest wheat producer, followed by Brazil (2.05 million ha), Chile ( 0.41 million ha), Paraguay (0.25 million ha), and Uruguay ( 0.14 million ha).

Rusts are important diseases affecting common wheat production in the Southern Cone of South America, causing severe losses if chemical control is not used. The cultivars grown (27 from Argentina, 18 from Brazil, 13 from Chile, 9 from Paraguay, and 10 from Uruguay) are largely moderately susceptible or susceptible to leaf rust, caused by Puccinia triticina (Table 1). In Argentina there is moderate exposure to stem rust. The estimated areas planted to cultivars with the 
Table 1. Total approximate areas $($ ha $\times 1000$ ) sown in 2004 to important cultivars, to cultivars moderately susceptible or susceptible to leaf and stem rusts, and to cultivars known to carry the 1BL.1RS translocation Estimated area sown to important cultivars; source: Argentina area sown (ha) in 2004, Secretaria de Agricultura Pesca y Alimentación; Brazil availability of certified seed, Departamento de Produção Vegetal, SAA-RS, Departamento de Fiscalização e Defensa Agropecuária/Divisão de Produção de Sementes, SAA-PR; Chile inscribed areas for 2002-2003, Servicio Agrícola y Ganadero; Paraguay Certified seed produced in 2004, Dirección de Semillas. MAG; Uruguay area sown (ha), Encuesta Agricola No. 227. MGAP. DIEA. Presence of 1B.1R. Source: Rosa Filho 1997; G. Tranquilli and L. Pflüger 2004, umpublished data; R. J. Peña 2003, unpublished data; and indirect evidence by the presence of $L r 26$ (Antonelli 2003; Germán et al. 2005; Zoldan and Barcellos 2002)

\begin{tabular}{|c|c|c|c|c|c|c|c|}
\hline \multirow[t]{2}{*}{ Country } & \multirow[t]{2}{*}{ Total } & \multicolumn{2}{|c|}{ Leaf rust } & \multicolumn{2}{|c|}{ Stem rust } & \multicolumn{2}{|c|}{$1 \mathrm{BL} / 1 \mathrm{RS}$} \\
\hline & & Area & $(\%)$ & Area & $(\%)$ & Area & $(\%)$ \\
\hline Argentina & 5498.7 & 4979.1 & 90.6 & 1743.6 & 31.7 & 3392.3 & 61.7 \\
\hline Brazil & 1753.5 & 1231.7 & 70.2 & 95.2 & 5.4 & 536.8 & 30.6 \\
\hline Chile & 170.1 & 99.2 & 58.3 & 9.7 & 5.7 & 70.5 & 41.4 \\
\hline Paraguay & 330.8 & 243.1 & 73.5 & 0.0 & 0.0 & 146.5 & 44.3 \\
\hline Uruguay & 158.4 & 112.9 & 71.2 & 22.7 & 14.3 & 33.6 & 21.2 \\
\hline Total & 7911.6 & 6666.0 & 84.3 & 1871.2 & 23.7 & 4179.7 & 52.8 \\
\hline
\end{tabular}

1BL.1RS translocation carrying stem rust resistance gene $\mathrm{Sr} 31$ exceeded half of the total wheat area.

Information on field reactions to leaf rust (Table 1) was available for all cultivars. The areas sown to cultivars moderately susceptible or susceptible to stem rust $(P$ graminis $f$. $\mathrm{sp}$. tritici) may be underestimated since stem rust reactions were available only for 56 cultivars, and some of the resistant cultivars may not be precisely characterised due to the absence of the disease in most of the area during recent years. The areas sown to cultivars with the 1BL.1RS translocation are also possibly underestimated, since the information on its presence was available for 47 cultivars. Information on stripe rust (P. striiformis f. sp. tritici) field reactions was available only from Chile where susceptible and moderately susceptible cultivars represented $64.7 \%$ of area sown to popular cultivars.

In the Southern Cone wheat is planted during the fall and winter. Spring wheat is grown in Brazil and Paraguay, and spring and facultative types grown in Argentina, Chile, and Uruguay. Winter types are grown in Southern Chile, and recently some winter wheats have been released in Argentina.

In the Atlantic area (Argentina, Brazil, Paraguay, and Uruguay), wheat is sown between latitude $18^{\circ}$ in Brazil and $38^{\circ} \mathrm{S}$ in Argentina, thus extending $2400 \mathrm{~km}$ from north to south. The crop is sown in lowlands $(<400 \mathrm{~m}$ asl) in Argentina, Uruguay, and Paraguay and on higher plateaux $(600-800 \mathrm{~m}$ asl) in Brazil. Annual average rainfall varies from $<400 \mathrm{~mm}$ in the south-western wheat region of Argentina to near $2000 \mathrm{~mm}$ in the northern wheat region of Brazil; in Paraguay average rainfall is $1600 \mathrm{~mm}$ and Uruguay has an intermediate annual rainfall of about $1000 \mathrm{~mm}$. In the Pacific area (Chile), wheat is planted in the central valley and in some lower Andean ranges along $2000 \mathrm{~km}$ between latitudes 27 and $43^{\circ} \mathrm{S}$. More recently, the crop has concentrated in the southern areas (latitudes $\left.35-43^{\circ} \mathrm{S}\right)$. The annual rainfall pattern is opposite to that of the Atlantic area, increasing from north to south, where it reaches $2000 \mathrm{~mm} /$ year. In both the Atlantic and the Pacific areas, the earliest crops are planted in the lower northern latitudes and later crops are planted in higher southern latitudes. Climatic conditions in southern Chile are very favourable for the development of stripe rust. Leaf rust and stem rust epidemics may occur throughout the entire Southern Cone, except in southwestern Argentina where low humidity and dew formation are limiting factors.

The importance of bread wheat rust diseases in the Southern Cone of South America, pathogen variability, the basis of resistance of the regional germplasm, and strategies used to control these diseases, as well as perspectives for the future, will be discussed.

\section{Wheat rusts}

Based on differences in the rusts race populations, 2 epidemiological zones were suggested for the region (Rajaram and Campos 1974). Chile, representing the western zone, is separated from the eastern zone (Argentina, Brazil, Paraguay, and Uruguay) by the Andean mountain range. According to van Beuningen and Kohli (1986), most areas in the Southern Cone have fluctuating local winds in addition to the predominant weather patterns and these are capable of distributing the spores in all directions. The Andean mountain range appears to delay the movement of races between the zones. As a result, there are some similarities between the west and east epidemiological zones in the $P$. triticina population (Barcellos and Kohli 2003), the P. striiformis population (Straib 1937), and the P. graminis f. sp. tritici population (Vallega 1955), indicating migration between zones. The presence of races of all 3 rust pathogens common to Chile and Argentina in cereal crops in the Andean valleys of Argentinean Río Negro and Neuquén provinces (Vallega and Favret 1947) also indicates a connection between the western and eastern epidemiological zones.

Studies on physiological specialisation of $P$. graminis $\mathrm{f}$. sp. tritici and $P$. triticina, identification of sources of resistance, and testing of breeding germplasm have a long tradition in Argentina and Brazil. The first studies in the Southern Cone were conducted by G. Rudorf and K. Rosentiel in Argentina (Rudorf et al. 1933). During 1938-1943 rust research was carried out by J. Vallega at the Instituto Fitotécnico de Santa Catalina, and during 1944-1952 by J. Vallega and E. Favret at the Instituto de Fitotecnia in Castelar (Vallega 
and Favret 1952). Studies were continued by E. Antonelli and other researchers until the 1990s at the Instituto Nacional de Tecnología Agropecuaria (INTA), Castelar Experimental Station. This research was discontinued in 1997 and restarted in 2002 by P. Campos at INTA Experimental Station in Bordenave. In Brazil, during 1949-1961 rust research was conducted by A. Silva at the Instituto de Pesquisas e Experimentação Agropecuária do Sul (IPEAS), in Pelotas, Río Grande do Sul (da Silva 1966), and later by E. Coelho and A. Barcellos. The rust program was transferred to the Empresa Brasileira de Pesquisa Agropecuária (EMBRAPA), Centro Nacional de Pesquisa de Trigo (CNPT), Passo Fundo, RS, also integrating other researchers (M. Madeiros, J. Sartori, M. Chaves, and others). Since 2002, leaf rust studies have also been conducted at OR Melhoramento de Sementes by A. Barcellos and C. Turra. Studies on physiological specialisation have been sporadic in Chile (Volovsky 1945, 1946), while no studies of this type have been conducted in Paraguay. Only a few studies were carried out in Uruguay before 1991 (Boasso and Levine 1951; Betucci et al. 1971), when a program to study cereal rusts with emphasis on P. triticina was initiated at the Instituto Nacional de Investigación Agropecuaria (INIA) by S. Germán. Since 1975, leaf rust and stem rust samples from Chile and Paraguay have been studied in Argentina, Brazil, or Uruguay, thus generating information for the entire region.

The exchange of germplasm and collaborative research among the Southern Cone countries, and with the international cereal rust research community, began in early 1900s, when wheat breeding was initiated in the region. Resistance to wheat leaf rust was present in the cultivars selected from landraces in the 1910s. These selections were extensively exchanged among breeding programs of Argentina, Brazil, and Uruguay. However, most of the germplasm developed during 1910-1950 was susceptible to stem rust. After the stem rust epidemic caused by race $15 \mathrm{~B}$ in the USA and Canada during 1950, all countries in the Southern Cone participated in the stem rust control program led by the University of Minnesota. The purpose of this international collaborative program was to evaluate the International Spring and Winter Wheat Rust Nurseries (ISWRN, IWWRN) from which sources of resistance to the 3 rusts could be selected and used in breeding programs. During the 1960s, rust resistant lines were also selected from germplasm distributed by the Rockefeller Foundation, and later by the International Maize and Wheat Improvement Center (CIMMYT) based in Mexico.

Cooperative research on wheat rusts among Argentina, Bolivia, Brazil, Chile, Paraguay, and Uruguay was started in 1975. The collaborative activities included testing of advanced lines from all countries for stripe rust in disease 'hotspots', distribution, and evaluation of new sources of resistance to all 3 rusts, evaluating new sources of adult plant resistance (APR) to leaf rust including local germplasm, and annual leaf rust and stem rust race surveys. More recent collaborative research integrates development of molecular markers for leaf rust resistance from Buck Manantial, phenotyping CIMMYT mapping populations for APR to leaf rust, development of mapping populations from regional sources of durable resistance, and introduction of APR to regional germplasm. The organisation and distribution of an ongoing annual Rust
Trap Nursery throughout the region was initiated by Brazil in 1975. Results from the Trap Nursery have been reported by A. Barcellos, E. Coelho, and co-workers at regional rust meetings. Results from 1998-2001 were summarised by Barcellos and Kohli (2003).

\section{Wheat leaf rust}

\section{Distribution and occurrence}

Leaf rust is currently the most prevalent and severe wheat disease in the Southern Cone (Kohli et al. 2003). It is present every year, causing widespread epidemics, depending on climatic conditions and area sown to susceptible cultivars. It causes severe epidemics in Brazil (Barcellos 1986), Paraguay (de Viedma and Bozzano 1986), and Uruguay (Germán and Kolmer 1994). In Argentina, leaf rust is the most widespread rust on wheat (Vallega and Favret 1952); however, only approximately $40 \%$ of the total area under wheat in Argentina is affected by severe leaf rust epidemics (Germán et al. 2004). In the remaining Argentinean wheat area, cool temperatures and dry conditions limit the disease development, although the disease can be observed over most of the wheat area. In Chile, leaf rust is increasing in importance, with more severe infections on winter and facultative wheats than on spring wheats (R. Madariaga 2003, pers. comm.).

Oversummering of leaf rust occurs over most of the region. Leaf rust has been observed in summer nurseries grown in southern Buenos Aires province and on volunteer plants throughout the Argentinean wheat area (Antonelli 2000), and on volunteer plants and trap nurseries planted during the summer in Uruguay. In Brazil, susceptible plants in pots have been placed in fields and later incubated, resulting in stem rust and leaf rust infections during most of the year (Barcellos et al. 1982; Barcellos 1986). Leaf rust infections in commercial fields are first observed in the north and develop with the crop towards the south of the region (Barcellos et al. 1982).

\section{Economic importance}

A very high proportion of the wheat area in the Southern Cone is planted with susceptible or moderately susceptible cultivars (Table 1), allowing widespread local oversummering and early onset of epidemics in the growing season. The replacement of susceptible cultivars is relatively slow and the easy availability of fungicides that efficiently control the disease has prolonged the lifespan of commercially popular cultivars. Losses caused by leaf rust can be $>50 \%$ in severe epidemics if fungicides are not applied. Losses estimated at US\$170 million were caused by epidemics on 10 important cultivars grown in the region during the period 1996-2003 (Germán et al. 2004). Considering the large areas sown to cultivars that require chemical control in an average epidemic, the total annual cost of fungicide applications to control leaf rust in the region is about US\$50 million.

The use of fungicides to control wheat leaf rust differs among countries. Fungicides have been recommended since 1977 in Brazil, have been used widely in Paraguay since 1976, and have been more commonly used in Uruguay since the 1990s. In normal epidemic conditions at least 2 applications of fungicides are required to control the disease on highly susceptible cultivars. 
In Argentina, one fungicide application to control leaf rust is used on about $35 \%$ of the wheat area. In Chile, the use of fungicides to control leaf rust is not as common, but in the last 5 years the use of chemical control has increased with the increased importance of the disease.

\section{The pathogen population and important epidemics} caused by new virulent races

The $P$. triticina population in the Southern Cone is extremely dynamic (Barcellos 2000; Antonelli 2003; Barcellos and Turra 2004; Germán et al. 2004; Chaves et al. 2005). A large number of races are generally present every year. The prevalence of pathogen races changes dramatically over time, in accordance with the area sown to cultivars susceptible to different pathotypes. After short periods of time, with few exceptions, resistance of widely grown cultivars is overcome by the appearance of virulent races of the pathogen (Barcellos 1982; Antonelli 2003).

Information on the most important $P$. triticina races found in recent surveys (race frequency and year of first detection) is presented in Table 2. About 1700 isolates collected in the region were studied during 2002-2004. Based on the 12 North American differentials (Long and Kolmer 1989) and 2 supplementary differentials (TcLr10 and TcLr20, listed after the Prt code when races are virulent on these lines), about 100 different virulence combinations were identified, including several new races. Most races were present at low frequencies. The number of races with frequencies $>10 \%$ within a given year varied from 1 to 4 . Generally, races found in high frequency during 2000-2004 were present in all Southern Cone countries, whereas races found in low frequency may have been present in only one country. The most important $P$. triticina pathotypes present in the region during the last 8 years were described by Chaves et al. (2005), and those present in Argentina during the last 2 years by Campos et al. (2005).

The prevalent races in the Southern Cone region are virulent for Lr1, Lr2a, Lr2c, Lr3a, Lr3ka, Lr10, Lr11, Lr14a, Lr14b, Lr16, Lr17a, Lr18, Lr20, Lr23, Lr24, Lr26, and Lr30 (Chaves et al. 2005). During the last 5 years, virulence frequencies have generally been high on lines with Lrl, Lr3a, Lr3ka, Lr10, LrI1, $\operatorname{Lr} 17 a, \operatorname{Lr} 26$, and $\operatorname{Lr} 30$, intermediate on lines with $\operatorname{Lr} 20$ and $L r 24$, and low on those with $\operatorname{Lr} 2 a, \operatorname{Lr} 2 c$, and $\operatorname{Lr} 9$. Based on field data from the trap nurseries, Barcellos and Kohli (2003) reported that genes $\operatorname{Lr} 19, \operatorname{Lr} 21, \operatorname{Lr} 29, \operatorname{Lr} 32, \operatorname{Lr} 36, \operatorname{Lr} 42$, and $\operatorname{Lr} 43$ were effective against the pathogen population present during 1998 2001. Since then, infection on $\operatorname{Lr} 19$ has been observed in the region. In Uruguay, seedling resistance genes $\operatorname{Lr} 28, \operatorname{Lr} 38$, and Lr41 and APR genes Lr22a and Lr35 confer field resistance. $\operatorname{Lr} 34$ is also effective throughout the region, although it expresses only a moderate level of resistance when present singly.

Races MFR, MCD-10,20, MCP-10, and MDR-10,20 and related races have been important recently. Races MFK, MFT, and MFR (Brazilian designation, B40) overcame the resistance of the popular Brazilian cultivars EMBRAPA 16 ( $L r 13$, Lr24) and OR $1(\operatorname{Lr} 23, L r 24)$, and the Uruguayan cultivar INIA Caburé (Lr24). These races, first combining virulence on $L r 24$ and $L r 26$, were important during 1997-2002 in Brazil, and in 2001 in Uruguay.

Race MCD and related races MHD, MHJ, MHK, and MHT, all virulent for $\mathrm{Lr} 10$ and $\mathrm{Lr} 20$ (Brazilian designation, B48), were present at high frequencies in Brazil until 2003, in Uruguay until 2002, in Chile in 2001, in Paraguay in 2003, and at

Table 2. Virulence formula and frequency of Puccinia triticina most important races identified in the Southern Cone in samples collected during 2002-2004

Source: A. Barcellos, M. Chaves, P. Campos, S. Germán, unpublished information

\begin{tabular}{|c|c|c|c|c|c|c|c|c|c|c|c|c|c|c|c|}
\hline \multirow{2}{*}{$\begin{array}{l}\text { Prt } \operatorname{code}^{\mathrm{A}} \text { and } \\
V \text { on } \operatorname{Lr} 10,20\end{array}$} & \multirow{2}{*}{$\begin{array}{l}\text { Brazil. } \\
\text { code }\end{array}$} & \multirow[t]{2}{*}{ Virulence formula } & \multicolumn{2}{|c|}{ First detection } & \multicolumn{3}{|c|}{2002} & \multicolumn{4}{|c|}{2003} & \multicolumn{4}{|c|}{2004} \\
\hline & & & Bra. & Uru. & Arg. & Bra. & Uru. & Arg. & Bra. & Par. & Uru. & Arg. & Bra. & Chi. & Uru. \\
\hline CCT-10 & & $3,3 \mathrm{ka}, 10,11,17,26,30$ & & 1998 & 16.8 & & 11.2 & 0.8 & & & 4.7 & 0.5 & & & 1.0 \\
\hline KDG-10,20 & & $2 a, 2 c, 3,10,11,20,24$ & & 1997 & 11.8 & & & & & & & & & & \\
\hline LPJ-10 & B44 & $1,9,10,11,17,24,26$ ' & 1997 & & & 9.8 & & & 0.7 & & & & 0.8 & & \\
\hline MCD-10 & & $1,3,10,17,26$ & & 2001 & 4.3 & & 4.1 & & 0.2 & & 1.8 & 2.4 & & & 15.0 \\
\hline MCD- 10,20 & B48 & $1,3,10,17,20,26$ & 1999 & 1999 & 5.6 & 1.1 & 26.5 & & 0.4 & 54.5 & 4.7 & 0.5 & 0.8 & & 6.0 \\
\hline MCG-10 & B34 & $1,3,10,11,26$ & 1989 & 1989 & 0.6 & & 1.0 & & 0.4 & 9.1 & 4.7 & 1.0 & & & 2.0 \\
\hline MCJ-10 & B34 & $1,3,10,11,17,26$ & 1989 & 2003 & & 6.6 & & & 9.9 & & 0.6 & 1.0 & 8.1 & & \\
\hline MCP-10 & & $1,3,3 \mathrm{ka}, 10,17,26,30$ & & 2000 & 21.7 & & 6.1 & 6.1 & & 18.2 & 12.4 & 14.4 & & & 28.0 \\
\hline MCP-10,20 & & $1,3,3 \mathrm{ka}, 10,17,20,26,30$ & & 2002 & 22.4 & & 1.0 & 1.5 & & & 3.0 & 1.4 & & & 2.0 \\
\hline MDR-10,20 & & $1,3,3 \mathrm{ka}, 10,11,20,24,30$ & & 2003 & & & & & & & 0.6 & 1.0 & & & 17.0 \\
\hline MFT & B40 & $1,3,3 \mathrm{ka}, 11,17,24,26,30$ & 1994 & & & 12.6 & & & 0.2 & & & & 1.2 & & \\
\hline MFT-10,20 & B55 & $1,3,3 \mathrm{ka}, 10,11,17,20,24,26,30$ & 2004 & & & & & & & & & & 6.5 & & \\
\hline MFT-20 & B51 & $1,3,3 \mathrm{ka}, 11,17,20,24,26,30$ & 2003 & & & 7.7 & & & 11.6 & & & 0.5 & 13.0 & & \\
\hline MHD- 10,20 & B48 & $1,3,10,16,17,20,26$ & 1999 & & & 10.9 & & & 7.0 & & & 0.5 & 2.4 & & \\
\hline MHJ-10,20 & B48 & $1,3,10,11,16,17,20,26$ & 1999 & & & 7.1 & & & 14.5 & & & & 6.5 & & \\
\hline MHK- 10,20 & B48 & $1,3,10,11,16,17,20,26,30$ & 1999 & & & 5.5 & & & 9.6 & & & & 5.3 & & \\
\hline MHP-10 & & $1,3,3 \mathrm{ka}, 10,16,17,26,30$ & & 2002 & & & 2.0 & 16.8 & & & & 22.0 & & & \\
\hline MHT-10 & B53 & $1,3,3 \mathrm{ka}, 10,11,16,17,26,30$ & 2003 & & & & & 49.6 & 0.7 & & & 30.6 & & & \\
\hline MHT- 10,20 & B48 & $1,3,3 \mathrm{ka}, 10,11,16,17,20,26,30$ & 1999 & 2002 & & 12.0 & 1.0 & 2.3 & 13.2 & & & & 6.5 & 100.0 & \\
\hline SPJ -10 & B50 & $1,2 a, 2 c, 9,10,11,17,24,26$ & 2002 & & & 4.9 & & & 8.1 & & & & 3.7 & & \\
\hline TDD-10,20 & $\mathrm{B} 43$ & $1,2 a, 2 c, 3,10,17,20,24$ & 1995 & 1995 & 1.2 & 0.5 & & 2.3 & & & 29.6 & 2.4 & & & 2.0 \\
\hline TFT & $\mathrm{B} 49$ & $1,2 a, 2 c, 3,3 \mathrm{ka}, 11,17,24,26,30$ & 2001 & & & 6.0 & & & 3.9 & & & & 1.6 & & \\
\hline TFT-20 & B54 & $1,2 a, 2 c, 3,3 \mathrm{ka}, 11,17,20,4,26,30$ & 2003 & & & & & & 2.2 & & & & 22.8 & & \\
\hline \multicolumn{3}{|c|}{ Total no. of samples per year } & & & 161 & 183 & 98 & 131 & 456 & 11 & 169 & 209 & 246 & 5 & 100 \\
\hline \multicolumn{3}{|c|}{ Total no. of races } & & & 19 & 24 & 28 & 21 & 35 & 5 & 31 & 27 & 26 & 1 & 19 \\
\hline \multicolumn{3}{|c|}{ Total no. of races freq. $>10 \%$} & & & 4 & 3 & 2 & 2 & 3 & 2 & 2 & 3 & 2 & 1 & 3 \\
\hline
\end{tabular}

A Long and Kolmer (1989). 
low frequencies in Argentina. These races caused important epidemics on the widely sown Brazilian cultivar BRS 49, and the Uruguayan cultivars Estanzuela Pelón 90 ( Lr1, Lr17, Lr26, Lr34, Germán and Kolmer 1996) and INIA Mirlo. MCD-10,20 was important in North America during 2002 (Kolmer et al. 2004; R. Singh 2003, pers. comm.), perhaps indicating the occurrence of intercontinental migration.

Race MCP-10, with a characteristic intermediate infection type on TcLr16, and MHP-10 are probably the same race. This race was found in high frequency in Argentina during 20022004, in Uruguay during 2003-2004, and in Paraguay during 2003. The leaf rust epidemics caused by MCP/MHP-10 on the Argentinean cultivar Klein Don Enrique ( $\mathrm{Lr} 26$ and additional resistance; Antonelli 2003), planted on over 2 million ha, were very severe and widespread during 2002 and 2003.

Race MDR-10,20, first identified in 2003, overcame the resistance of the Uruguayan cultivars INIA Torcaza ( $\operatorname{Lr} 10, \mathrm{Lr} 24$; Germán et al. 2005) and INIA Churrinche, and the widely grown Brazilian cultivar Ônix. The frequency of this race rapidly increased in Uruguay during 2004 and in Argentina and Brazil in 2005.

Some important epidemics that occurred on regional cultivars since the 1990s, due to the spread of races with new virulence combinations, were described by Antonelli (2003) and Germán et al. (2004).

Virulence has frequently develoned for effective resistance genes deployed in commercial cultivars in the Southern Cone. Virulence on wheats with Lr26 was first detected in Argentina in 1980 (Antonelli 2003) and in Bazil in 1982 (Barcellos 1986). Many CIMMYT lines and derivatives released in the region (Kohli and Skovmand 1997) became susceptible due to races with $\operatorname{Lr} 26$ virulence. Virulence for $L r 2 \div$, first detected in 1981 both in Argentina (Antonelli 1982) and Brazil (Barcellos and Aita 1982), caused extremely severe epicemics during 1982 on the Argentinean cultivar Cargill Trigal 80), and on the cultivar Tifton, grown in Brazil. Virulence for $L \%$, first detected in Argentina in 1982 (Antonelli 1986), causec' a major epidemic during 1985 on the Argentinean cultivar La Paz INTA, grown in Argentina and Uruguay (Germán et al. 1986). Virulence for $L r 37$ was first demonstrated in Uruguay in 1999 in race MCD-10,20, which affected several cultivars that do not carry $L r 37$. Virulence on $\operatorname{Lr} 19$ was first observed in 2004 in Paraguay (de Viedma et al. 2005) and Argentina, where it was verified by E. Antonelli (2005, pers. comm.). During 2005 the Argentinean cultivar ProINTA Gaucho, which probably has $\operatorname{Lr} 19$, was severely affected by leaf rust.

\section{Breeding for resistance}

During the first period of wheat breeding in the region, leaf rust resistance was mainly derived from locally adapted germplasm, which in many cases was also used by breeding programs in other countries. The Brazilian cultivar Frontana ( $L r / 3, L r 34$, LrT3 and additional adult plant resistance; Dyck et al. 1966; Dyck and Samborski 1982; Singh and Rajaram 1992) and the Argentinean cultivar Buck Manantial ( $L r 3 a$ or an allele, LrI6, and $L r 17 a, L r 13$, and possibly Lr34; Dyck 1989) are sources of durable resistance that have been used internationally. Sources of resistance were selected from germplasm distributed by
USDA since the 1950s and by the Rockefeller Foundation (later, CIMMYT) since the 1960s. Many CIMMYT lines derived leaf rust resistance from South American germplasm (Rajaram et al. 1988)

Seedling resistance genes present in the regional germplasm developed before 1960 are $L r 1, L r 3 a, L r 3 b g, L r 3 k a, L r 11, L r 14 b$, Lr16, and Lr17a (Dyck and Samborski 1968a, 1968b, 1970; Haggag and Dyck 1973; Dyck and Kerber 1977; Antonelli 1983; Roelfs 1988; Dyck 1989; Kolmer et al. 2007; E. F. Antonelli 2005, unpublished data). Two previously undesignated seedling resistance genes, temporarily designated $\operatorname{Lr} 7 \mathrm{D}$ and $\operatorname{Lr} 44 \mathrm{~d}$ (originally present in the Argentinean cultivar Barletta 7D, and the Uruguayan cultivar Americano 44d, respectively), were described by Antonelli (1994). Kolmer et al. (2007) found a previously unidentified gene in Americano 25e.

Adult plant resistance genes $\operatorname{Lr} 12, \mathrm{Lr} 13$, and $\operatorname{Lr} 34$ are also present in the traditional germplasm (Dyck et al. 1966; Dyck and Samborski 1982; Roelfs 1988; Dyck 1989; Singh and Rajaram 1992; Kolmer et al. 2007). Brazilian cultivar BH 1146 has Lr13 and Lr34 (Kolmer and Liu 2001). Under the extremely favourable conditions for leaf rust development present in the region, $L r 34$ and other APR genes were probably selected from the heterogeneous landrace cultivars, and then maintained in newer cultivars. Singh and Rajaram (1992) claimed evidence for APR genes additional to $\operatorname{Lr} 13$ and $\operatorname{Lr} 34$ in Frontana. Kolmer et al. (2007) found one APR gene different from $L r 12, L r 13$, or Lr34 in Americano 25e, and 2 possibly unique APR genes in Americano 26n.

More recently released cultivars in South America have been derived from germplasm obtained from CIMMYT and other breeding programs. Seedling resistance genes $\operatorname{Lr} 10$, Lr14a, Lr19, Lr23, Lr26, Lr27, and Lr31 (Singh and Rajaram 1991; Singh 1993) may have been introduced with CIMMYT germplasm. Lr26 is probably the most widely distributed of these genes since it is present in many highyielding CIMMYT lines (e.g. Veery, Bobwhite, Alondra, Kauz, and others) and derivatives that have been used directly as cultivars or in local crosses. In Chile, Lr26 was also introduced through direct use of European wheats carrying the 1BL.1RS translocation (e.g. Aurora, Kavkaz, Bezostaya, Lovrin, Mildress, Clement; I. Ramirez, pers. comm.). $\operatorname{Lr} 9$ is present in Precoz Paraná INTA and its derivative La Paz INTA (Antonelli 1983). Lr24 is present in Cargill Trigal 800 (Antonelli 2003) and other Agent derivatives used in breeding programs in Argentina and Uruguay, and in Amigo, Tifton, and Century, used in Brazil (Barcellos 1991 cited by Zoldan and Barcellos 2002; The et al. 1991; McIntosh et al. 1995). Lr34 and other APR genes conferring durable resistance are widely distributed in CIMMYT germplasm (Singh and Rajaram 1992; Singh and Huerta-Espino 1995), mostly derived from traditional Southern Cone germplasm, and in current regional cultivars.

Resistance genes Lr10, Lr23, Lr24, and Lr26, most common in Brazilian germplasm tested during 1996-97 (Zoldan and Barcellos 2002), continued to be present in the most important cultivars used in 2004. Lr13 and Lr34 are also widely present in the Brazilian germplasm (Zoldan et al. 2000; de Sousa and Barcellos 2000, 2001), together with other APR genes such as Trp1 and Trp2 (temporary designation) present in Toropí 
(Barcellos et al. 2000) and an undesignated APR gene present in BR35 (Brammer et al. 2004). A backcross program conducted in EMBRAPA CNPT, Brazil, since 1975 was designed to incorporate genes for leaf rust resistance ( $\operatorname{Lr} 9, \operatorname{Lr} 19, \operatorname{Lr} 22 \mathrm{a}$, Lr24, Lr25, and others) in susceptible locally adapted lines (Barcellos and Aita 1982), although these genes are not widely deployed in commercial cultivars. Genes Lrl, Lr 3a, LrO, LrIO, LrI Ha, Lr16, Lr17a, Lr23, Lr24, and Lr26 have been postulated in modern Argentinean cultivars (Antonelli 2003), and now, newer resistance genes $L r 37$ and $L r-47$ (Lewis et al. 2003) and Lr.5I are being transferred to adapted materials by the use of marker assisted selection, and $L r 43$ by backcrossing. Genes Lr13, Lr3bg, Lr10, LrI Ha, LrI 4b, Lr16, LrI7a, Lr24, Lr26, and APR genes Lr.13 and Lr34 have been found or postulated in Uruguayan cultivars released since 1980 (Germán and Kolmer 1996; Germán et al. 2005).

Resistance in current cultivars is most commonly based on combinations of previously mentioned genes. There is limited knowledge of the basis of resistance present in commercial cultivars and many of the sources of resistance, slowing genetic progress in obtaining effective and long-lasting resistance. Since the mid 1990s, more emphasis has been placed on durable resistance. The use of APR conditioned by minor genes with additive effects is considered the best strategy to control leaf rust and to stabilise the pathogen population (Barcellos 1991, 2000; Antonelli 2003; Singh et al. 2003; Barcellos and Turra 2005; Germán et al. 2005; de Viedma et al. 2005). Lr34 is widely present in the regional germplasm and it is important that it be maintained in combinations with other resistance sources. Some CIMMYT lines with additive minor gene resistance (Singh et al. 2003) have shown low leaf rust severities in the Southern Cone and are being increasingly used in crosses. Some regional cultivars (Toropi and BR35) and adapted lines with APR identified from regional nurseries are also being used as sources of resistance. Research is being conducted to identify better molecular markers for Trpl and Trp2 (da Silva 2002), located on chromosomes $1 \mathrm{~A}$ and 4D (Brammer et al. 1998). In Argentina, markers for genes conferring the durable resistance of Buck Manantial are being developed (F. Sacco 2005, pers. comm.). The availability of these markers is likely to increase the efficiency of breeding for durable resistance.

Collaborative research between public and private breeding programs is under way to increase the use of durable APR in crosses. One limitation to genetic progress in the incorporation of this resistance using CIMMYT germplasm and many lines from the region is that the material with APR to leaf rust is susceptible to fusarium head blight (caused by Fusarium spp.), which is a serious disease of wheat in the Atlantic area, and to some of the prevalent leaf blights (caused mainly by Septoria, Bipolaris, and Drechslera spp.). Therefore, some programs, while considering the use of APR as the best long-term solution for leaf rust, are still using race-specific scedling resistance genes as a basis of resistance in adapted germplasm.

In the short-term, the situation of large areas sown to susceptible cultivars is not likely to change. A study of the leaf rust resistance in advanced lines from various wheat-breeding programs across the region over the past 20 years (approximately 300 lines per year) indicated that the proportion of resistant lines increased slightly from 1981 to 1993 . However, during 1995-2000, there was a marked reduction in resistant and moderately resistant materials (Kohli et al. 2003). If the breeding programs are successful in breeding for APR and the area sown to cultivars with stable resistance increases, the disease will probably decrease in importance. This will hopefully stabilise the pathogen population and reduce the need to use fungicides for disease control.

\section{Stripe rust}

\section{The western epidemiological zone: Chile}

Stripe rust is endemic in the western epidemiological zone. It is the most important rust in the wheat area in southern Chile, where it is favoured by cool conditions of a high latitude environment. In this area, stripe rust is present every year, with severe infections mostly on winter and facultative wheats (Hacke 1990). A severe epidemic occurred in 1940, and during 19761988 stripe rust caused economic losses at least once every 2 years (Andrade Vilaro 1990). Although stripe rust infections have not caused major concern over the past few years, an early epidemic in 2001 affected several spring cultivars, especially those carrying $\mathrm{Yr} P$, such as Nobo INIA.

Frequent changes of virulence occur in the pathogen population, causing increasingly higher infections on initially resistant cultivars. Numerous races were identified by Straib (1937) and Stubbs (Andrade Vilaro 1990). Annual surveys of the pathogen population have been sporadic and updated information is lacking. After 2001, no changes in field reaction of cultivars and single gene lines have been observed ( $R$. Madariaga 2005 , pers. comm.), indicating that no significant changes in the pathogen population occurred.

According to the field reactions of the differential lines in the Avocet $\mathrm{S}$ genetic background, genes Yr5, Yrs, Yrlo, $Y_{r} 15$, and $Y r S p$ have been effective during the last few years in Chile (Madariaga et al. 2004). Jupateco R with Yrls was moderately susceptible, and the Avocet S NIL with Yr.9 was highly susceptible.

When the resistance of commercial cultivars is overcome by virulent races, chemical control is required to prevent severe losses (Andrade Vilaro 1990; Madariaga et al. 2004). Chemical control of stripe rust was initiated in the late 1970s and was widely adopted after the mid 1980s, particularly by farmers using advanced technologies (O. Andrade Vilaro 2005, pers. comm.).

In Chile, breeding for stripe rust resistance started in 1960 . The strategy was to cross locally adapted germplasm with sources of resistance such as Heines VII, Selkirk, CapelleDeprez, Clement, and other winter European cultivars, materials selected from the IWWRN and ISWRN, CIMMYT germplasm, and some local Chilean cultivars (Aguayo 1983; Hewstone 1983; Hacke 1990; Madariaga et al.2004). Presently, the use of sources of durable resistance, now available and well characterised (Singh and Rajaram 1994; Singh et al. 2003), is a priority.

The eastern epidemiological zone: Argentina, Brazil, and Uruguay

Stripe rust was first observed and described in Argentina and Uruguay in 1929 (Rudorf and Job 1931, cited by Vallega 1938). During 1929 and 1930, stripe rust caused very extensive 
epidemics in most of the region (from Chile to Río Grande do Sul in Brazil) causing extremely high losses in the eastern epidemiological zone (Boerger 1934; Vallega 1938). The presence in Argentina and Uruguay of common races found in Chile (Straib 1937) indicates stripe rust probably migrated through the Andes from Chile to the eastern part of the continent.

Yr18 and tightly linked Lr34 (McIntosh 1992; Singh 1992) were probably present in tolerant wheat lines selected under the extreme 1929 and 1930 stripe rust epidemics, as suggested by Dyck (1991) and Kolmer (1996). The Brazilian cultivar Fronteira, one of Frontana's parents, selected at Bagé Experimental Station and released in 1934, was highly resistant to stripe rust (Beckmann 1940). In Argentina, cv. Chino, also known as Chinese 166, expressed the most effective resistance and was used in crosses from which adapted resistant lines were derived (Vallega 1938).

Unlike other regions of the world where the importance of stripe rust is increasing, no other widespread epidemic has occurred in the eastern epidemiological zone and the disease is currently not economically important. In the southern wheat area of Argentina only sporadic localised outbreaks have been observed on highly susceptible cultivars. Similar localised epidemics have also been observed in southern Brazil, affecting cv. Curitiba during 1968 (Schramm 1969), and cv. Tifton during 1980. In 1998 a moderate epidemic of stripe rust occurred in Uruguay (Germán and Caffarel 1999). During this epidemic, some cultivars with the 1BL.1RS translocation, such as Estanzuela Cardenal (Veery \#3) were susceptible, indicating the presence of virulence on $\operatorname{Yr} 9$. Many cultivars known to carry Yr18/Lr34 had low to intermediate stripe rust severities.

Puccinia striiformis probably oversummers in the valleys of the Argentinean Andes (Neuquén and Río Negro provinces) on wheat and wild Hordeum spp. (Vallega and Favret 1947) delaying the dispersal of inoculum to the major production areas in the north. Most germplasm from Argentina, Brazil, Paraguay, and Uruguay is moderately susceptible or susceptible under the heavy disease conditions present in Chile. The absence of early infections, even in the presence of susceptible cultivars, indicates that inoculum is usually not present at early stages of crop development, and that oversummering does not regularly occur in the main wheat areas. Under these conditions, avoiding the use of highly susceptible cultivars, and maintaining resistance levels such as those conferred by $\mathrm{Yr} 18$ or other genes with similar effect, appears to be an effective strategy to prevent stripe rust epidemics in Uruguay (Germán and Caffarel 1999) and the rest of the eastern epidemiologic zone. In addition, the increased use of durable APR to leaf rust, often associated with APR to stripe rust (Singh 1992; Singh and Rajaram 1994; Singh et al. 2003), will also increase the level of resistance to stripe rust.

\section{Wheat stem rust}

\section{Distribution and occurrence}

Although the incidence of stem rust historically has been more sporadic than that of leaf rust, it caused higher levels of damage during severe epidemics. It was considered the most destructive wheat rust in Brazil (da Silva 1966), Paraguay (de Viedma and
Bozzano 1986), Uruguay (Ribeiro 1952), the northern wheat growing area of Chile (Hacke 1990) and the northern and centralnorth wheat area of Argentina (Vallega and Favret 1952).

Oversummering of stem rust has been observed on volunteer wheat and barley plants in Uruguay and in the south of Buenos Aires province (Argentina) where it is frequently present in the summer nursery at Balcarce (J. Nisi 2005, pers. comm.). Stem rust also oversummers locally in Brazil (Barcellos et al. 1982).

A very severe stem rust epidemic occurred in Argentina and other Southern Cone countries in 1950 (Antonelli 2000). The majority of commercial cultivars from regional breeding programs were susceptible to the pathogen population, dominated by a variant of race 15 (effective genes $\operatorname{Sr} 6,7 a, 22,24,25,26,27,31 /$ ineffective genes $\operatorname{Sr} 8 a, 8 b, 9 e, 9 a, 9 g$, 10,11,13,17,30,37, denominated 15 (63) by Antonelli 1969). In 1974 , a new race (effective genes $\operatorname{Sr} 8 a, 8 b, 9 e, 11,22$, 24,25,26,27,31,37/ineffective genes $\operatorname{Sr} 6,7 a, 9 a, 9 g, 10,13,17,30$, denominated $11 \mathrm{MeR}$ in Argentina, and G11 in Brazil), virulent on most of the popular Argentinean (Antonelli 2000), Brazilian (Coelho 1980), and Uruguayan cultivars (Luizzi et al. 1980), caused widespread epidemics under unusually favourable environmental conditions during 1975-1976.

Wheat stem rust has not been severely epidemic for over 2 decades. This was coincident with the increased and widespread use of cultivars with 1BL.1RS (Sr31) (Antonelli 2000). During 1975-2003, 2 stem rust epidemics (1976 and 1981) were observed in Passo Fundo, RS, Brazil (C. de Souza 2005, pers. comm.). Localised epidemic outbreaks occurred during the 1990s on some widely grown cultivars in Paraguay (Itapúa 35), Brazil (CEP 14), and Argentina (Victoria INTA). Since 2000 , stem rust has been observed sporadically on highly susceptible materials in experimental fields throughout the region. The release of stem rust susceptible cultivars such as Klein Escorpión, Buck Yatasto, and the French cultivar Baguette 10 led to the reappearance of the disease in commercial fields in northern Argentina in 2001 and 2003 (J. Nisi 2005, pers. comm.).

\section{The pathogen population}

During 1949-1994, 30 different $P$. graminis races were described in Brazil. These combined virulence on 4 to $14 \mathrm{Sr}$ genes $(\mathrm{Sr} 5$, Sr6, Sr7a, Sr8, Sr9a, Sr9b, Sr9e, Sr10, Sr11, Sr12, Sr13, Sr14, $\operatorname{Sr} 17, \operatorname{Sr} 29, \operatorname{Sr} 30, \operatorname{Sr} 36, \operatorname{Sr} 37)$. Most old races identified in Argentina and Brazil were lost from the collections due to reduction in research on stem rust. Few races have been found since 2000. One race (RTT-TR, Brazilian designation, G30) has been prevalent for many years in Brazil and Uruguay. Since 2002 some changes in the pathogen population have been detected in Brazil (A. Barcellos; C. de Souza, S. Germán, C. Turra, and M. Segalin 2003, unpublished data), Argentina, and Uruguay. Genes $\operatorname{Sr} 22, \operatorname{Sr} 24, \operatorname{Sr} 25, \operatorname{Sr} 26, \operatorname{Sr} 31, \operatorname{Sr} 32, \operatorname{Sr} 33$, $\mathrm{Sr} 35, \mathrm{Sr} 39$, and $\mathrm{Sr} 40$ are currently effective across the region. Sr 27 had intermediate stem rust severity levels in Chile in 1984 (Hacke 1986). Sr 38 has not been tested, although CIMMYT line Milan that may carry this gene has had high field severity with susceptible reaction to stem rust in Uruguay and Paraguay. In 2005 , a very severe stem rust epidemic on international nurseries from CIMMYT and the Southern Cone region was observed in Santa Cruz, Bolivia. 


\section{Breeding for resistance}

Stem rust resistance was one of the major wheat breeding objectives when the disease was important across the region. In some countries, stem rust resistance was a requirement for cultivar release. Sources of stem rust resistance were selected from the same international nurseries used to select for leaf rust resistance. During the 1950 s and 1960s, sources of resistance identified in Argentina were Kenya 58, Kenya 117A, Egypt NA 101, some lines from Egypt N95, Kenya Governor, Kenya Standard (Vallega 1940), Mayo 54, Kentana 51A, Yaqui 53, and new resistance identified from the ISWRN (Antonelli 2000). In Brazil, the best sources of resistance provided to breeding programs were Red Egyptian, Kenya 58, and Kenya Farmer. Cultivars with resistance from these sources became widespread (da Silva 1966)

Sr22, Sr24, Sr25, Sr26, Sr27, Sr31, Sr32, Sr33 (Coelho 1982, 1986) and $\operatorname{Sr} 2$ (C. Sousa, pers. comm.) have been used in EMBRAPA-CNPT. In the Brazilian company OR, sources with slow rusting type of resistance are being used.

Presently, the most important genes conferring resistance in the regional germplasm are $\operatorname{Sr} 31$ and $S r 24$. The presence of $S r 31$ is indicated by the presence of the 1BL.1RS translocation and/or the presence of $L r 26$. The presence of $L r 24$ indicates the presence of $\operatorname{Sr} 24$. The introduction and use of $\operatorname{Sr} 31$ and $S r 24$ in the regional germplasm were as described for the linked leaf rust resistance genes. Although it is not known if $S r 24$ and Sr 31 are present singly or in combination with other resistance genes, the basis of resistance in the regional germplasm appears to be narrow. Genes Sr 5, Sr6, Sr $7 a$, Sr8a, Sr8b, Sr9b, Sr 10, Sr11, and Sr 30 are probably present (but largely ineffective) in some Argentinean cultivars (Antonelli 2000). APR genes such as Sr2, are present in many Brazilian lines and cultivars (C. de Souza 2005, pers. comm.).

The absence of the disease and reduced pathogen variability has decreased the opportunities of selection for resistance, and also the priority that breeding programs have assigned to this characteristic. As a result, some susceptible cultivars have been recently released, including some of European origin. It was estimated that $>20 \%$ of the regional wheat area in 2004 was sown to cultivars known to be susceptible to stem rust (Table 1), and this area continues to increase. The increasing area of susceptible cultivars may result not only in inoculum build-up and higher infections on these cultivars, but also to an increased likelihood of developing new virulent races on currently resistant cultivars. In addition, the introduction of races with $\mathrm{Sr} 24$ virulence from South Africa or India could cause significant losses. Because the 1BL.1RS translocation is present in a high proportion of the regional germplasm $(>50 \%$ of the wheat area is sown with cultivars with this translocation, Table 1), the possibility of introduction of the Sr3I virulent race Ug99 from Africa is of concern (Antonelli 2000; Germán et al. 2005; I. Ramirez 2005, pers. comm.). This could result in significant epidemics, since data obtained in Kenya during 2005 indicated that the large majority of a group of 72 current regional cultivars are susceptible or moderately susceptible (R. Wanyera 2005, pers. comm.). Given this situation, stem rust may increase in importance in the near future, and it is urgent to increase testing for resistance to this disease. The introduction of resistance genes effective against races virulent on lines with $\operatorname{Sr} 31$ and $S r 24$, as well as other effective genes not present in the regional germplasm, should be emphasised (Germán et al. 2005).

The control of wheat rusts continues to be a challenge for breeders and rust pathologists in the Southern Cone of South America. Breeding wheat cultivars with effective and more durable resistance is being addressed using traditional methodologies as well as gradually introducing newer tools to help increase knowledge about rust resistance and its efficient use in breeding.

\section{Acknowledgments}

We appreciate the contribution of Dr Ricardo Madariaga, INIA-Chile, and Dr Robert McIntosh, University of Sydney, for reviewing the paper. Much of the information from 1999-2004 was obtained during the execution of a project funded by USDA. Funding of the attendance of the main author to the conference 'Global Landscapes in Cereal Rust Control' (September 2005) by GRDC is greatly appreciated.

\section{References}

Aguayo L (1983) Mejoramiento de trigos invernales y primaverales en la zona centro-sur de Chile. In 'Reunião de Melhoristas de Trigo do Cone Sul’. EMBRAPA-CNPT, Passo Fundo, RS. (Coord. O de S Rosa) pp. 91-100. Diálogo No. 9. (Programa Cooperativo de Pesquisa Agricola: Montevideo)

Andrade Vilaro O (1990) Polvillo estriado o roya amarilla (Puccinia striiformis Westend) del trigo en la zona sur de Chile. Instituto de Investigaciones Agropecuarias, Estación Experimental Carillanca, Boletín Técnico No. 164, Temuco.

Antonelli EF (1969) Fuentes de germoplasma de resistencia a enfermedades y plagas. In 'Simposio del trigo'. Buenos Aires. pp. 332-351. (Academia Nacional de Agronomía y Veterinaria: Buenos Aires)

Antonelli EF (1982) Especializacion fisiológica de Puccinia recondita tritici y $P$. graminis tritici en la Argentina en el periodo 1978-1981. In 'Reunión de Especialistas en Royas del Trigo, Cono Sur de América'. INTA Castelar, Argentina. [s.p.]. (Programa IICA-Cono Sur/BID)

Antonelli EF (1983) Principales patógenos que afectan la producción de trigo en la Argentina. In 'Simposio sobre Fitomejoramiento y Producción de Cereales'. INTA/CIMMYT Marcos Juárez, Córdoba. [s.p.]. (Agencia Estadounidense para el Desarrollo Internacional, Universidad Estatal de Oregon)

Antonelli EF (1986) Especialización fisiológica de Puccinia recondita tritici y P. graminis tritici en la Argentina en el periodo 1982-1984. In 'Reunião de Especialistas em Ferrugens de Cereais de Inverno'. CNPT/EMBRAPA, Passo Fundo, RS. (Ed. CJ Molestina) pp. 37-39. Diálogo No. 13. (PROCISUR: Montevideo)

Antonelli EF (1994) Resistencia en plántula y planta adulta de cultivares comerciales argentinos de trigo y progenitores (antecesores) tradicionales. In 'Interacción hospedante-patógeno en hongos biotrofos. Informe correspondiente al año 1993. [s.p.]. (Instituto de Genética E.A. Favret: Castelar)

Antonelli EF (2000) La roya negra del tallo (Puccinia graminis f. sp. tritici). Una ilustre ausente de los campos de trigo. ¿Por cuánto tiempo más? (Grafos: Necochea, Argentina)

Antonelli EF (2003) La roya anaranjada (Puccinia triticina Erikss.). Sobre la efimera resistencia observada en la última década en cultivares comerciales de trigo de amplia difusión en la Argentina. (Grafos: Necochea, Argentina)

Barcellos AL (1982) As ferrugens do trigo no Brasil. In 'Trigo no Brasil'. (Coord. EA Osório) pp. 377-419. (Fundacão Cargill: Campinas) 
Barcellos AL (1986) Ferrugem da folha do trigo no Brasil. População patogênica, fontes de resistência, trigos comerciais, perpetuação e controle químico. In 'Reunião de Especialistas em Ferrugens de Cereais de Inverno'. CNPT/EMBRAPA, Passo Fundo, RS. (Ed. CJ Molestina) pp. 72-87. Diálogo No. 13. (PROCISUR: Montevideo)

Barcellos AL (1991) Durable leaf rust resistance in wheat in Brazil. In 'Wheat for the non-traditional warm areas'. (Ed. D Saunders) pp. 462-465. (CIMMYT: México DF)

Barcellos AL (2000) Urgent need for less ephemeral resistance to leaf rust in Brazilian wheat cultivars. In '6th International Wheat Conference'. Agricultural Research Institute of the Hungarian Academy of Sciences, Martonvásár, Hungary.

Barcellos AL, Aita L (1982) Sintese dos resultados das pesquisas sobre ferrugem da folha do trigo realizadas no CNPT-EMBRPA, Passo Fundo, RS, Brasil, de 1980 a 1982. In 'Reunión de Especialistas en Royas del Trigo, Cono Sur de América'. INTA Castelar, Argentina. [s.p.]. (Programa IICA-Cono Sur/BID)

Barcellos AL, Aita L, Coehlo ET (1982) Informações preliminares sobre fonte de inóculo de ferrugem da folha e do colmo do trigo em Passo Fundo. In 'Reunión de Especialistas en Royas del Trigo, Cono Sur de América'. INTA Castelar, Argentina. [s.p.]. (Programa IICA-Cono Sur/BID)

Barcellos AL, Kohli MM (2003) Resultados da XI ${ }^{\mathrm{a}}, \mathrm{XII}^{\mathrm{a}}$, XIII ${ }^{\mathrm{a}}$, e XIV ${ }^{\mathrm{a}}$ coleção para avaliação e coleta de ferrugem do colmo e ferrugem da folha do trigo 1998-2001. EMBRAPA Trigo/CIMMYT, Documentos no. 37, Passo Fundo.

Barcellos AL, Roelfs AP, de Moraes-Fernandes MIB (2000) Inheritance of adult plant leaf rust resistance in the Brazilian wheat cultivar Toropi. Plant Disease 84, 90-93.

Barcellos AL, Turra C (2004) Search for durable resistance to wheat leaf rust in Brazil. In 'Abstracts [of the] 11th International Cereal Rusts and Powdery Mildews Conference'. John Innes Centre, Norwich, England, UK. p. A2.3

Barcellos AL, Turra C (2005) Partial resistance - best approach for control of wheat leaf rust in environments favorable for the disease. In 'Wheat production in stressed environments: abstracts of oral and poster presentations [of the] 7th International Wheat Conference'. Mar del Plata, Argentina. pp. 125. (Secretariat of Agriculture, Animal Husbandry, Fisheries and Food)

Beckmann I (1940) El problema del trigo en el Brasil. Revista de la Facultad de Agronomia, (Montevideo) 19, 21-36

Betucci L, Ferreira V, Szpiniak B (1971) Razas fisiológicas de Puccinia graminis tritici y Puccinia recondita tritici presentes en el Uruguay en 1968. Universidad de la República, Boletín No. 117, Montevideo.

van Beuningen LT, Kohli MM (1986) Results from the observations on the Latin American Rust Nursery (ELAR 1981-1983). In 'Reunião de Especialistas em Ferrugens de Cereais de Inverno'. CNPT/EMBRAPA, Passo Fundo, RS. (Ed. CJ Molestina) pp. 7-20. Diálogo No. 13. (PROCISUR: Montevideo)

Boasso CS, Levine MN (1951) Leaf rust of wheat, Puccinia rubigovera tritici, in Uruguay. Phytopathology 41, 736-741.

Boerger A (1934) Consideraciones restropectivas acerca de la primera aparición epidémica de la roya amarilla (Puccinia glumarum (Schm) Erikss. et Henn.) en el Río de la Plata. Revista del Ministerio de Industrias (Montevideo) 1, 5-16.

Brammer SP, Fernandes MIB, Barcellos AL, Milach SCK (2004) Genetic analysis of adult-plant resistance to leaf rust in a double haploid wheat (Triticum aestivum L. em Thell) population. Genetics and Molecular Biology 27, 432-436. doi: 10.1590/S1415-47572004000300020

Brammer SP, Worland A, Barcellos AL, Fernandez MIB (1998) Monosomic analysis of adult-plant resistance to leaf rust in the Brazilian wheat cultivar "Toropi". In 'Proceedings 9th International Wheat Genetics Symposium'. Saskatoon, Saskatchewan. (Ed. AE Slinkard) v.2, pp. 17-18. (University of Saskatchewan)
Campos PE, López JR, Brach AM (2005) Characterization of population of Puccinia triticina in Argentina in 2003 and 2004. In 'Wheat production in stressed environments: Abstracts of oral and poster presentations of the 7th International Wheat Conference'. Mar del Plata, Argentina. p. 129. (Secretariat of Agriculture, Animal Husbandry, Fisheries and Food)

Chaves MS, Barcellos AL, Germán S, Scheeren PL, Del Duca LdeJA Silva M Só e, Caierão E (2005) Population dynamics of Puccinia triticina in the South Cone region of South America. In 'Wheat production in stressed environments: Abstracts of oral and poster presentations [of the] 7th International Wheat Conference'. Mar del Plata, Argentina. p. 130. (Secretariat of Agriculture, Animal Husbandry, Fisheries and Food)

Coelho ET (1980) Distritribução, prevalencia de novas razas fisiologicas de Puccinia graminis tritici (ferrugem do colmo do trigo) no Brasil de 1974 a 1978. In 'XI Reunião Nacional de Pesquisa de Trigo'. Porto Alegre, RS, Brasil. v. 2, pp. 9-22. (EMBRAPA Centro Nacional de Pesquisa de Trigo: Passo Fundo)

Coelho E (1982) Síntese dos resultados das pesquisas sobre ferrugem do colmo do trigo realizadas no Centro Nacional de Pesquisa de Trigo (CNPT) EMBRAPA, Passo Fundo, RS, Brasil 1980 e 1981. In 'Reunión de Especialistas en Royas del Trigo, Cono Sur de América'. INTA Castelar, Argentina. [s.p.]. (Programa IICA-Cono Sur/BID)

Coelho E (1986) Síntese dos estudos com ferrugem do colmo do trigo -1982 a 1984. In 'Reunião de Especialistas em Ferrugens de Cereais de Inverno'. CNPT/EMBRAPA, Passo Fundo, RS. (Ed. CJ Molestina) pp. 107-110. Diálogo No. 13. (PROCISUR: Montevideo)

Dyck PL (1989) The inheritance of leaf rust resistance in wheat cultivars Kenyon and B. Manantial. Canadian Journal of Plant Science 69, 1113-1117.

Dyck PL (1991) Genetics of adult plant leaf rust resistance in Chinese Spring and Sturdy wheats. Crop Science 24, 309-311.

Dyck PL, Kerber ER (1977) Inheritance of leaf rust resistance in wheat cultivars Rafaela and EAP 26127 and chromosome location of Lr17. Canadian Journal of Genetics and Cytology 19, 355-358.

Dyck PL, Samborski DL (1968a) Genetics of resistance to leaf rust in the common wheat varieties Webster, Loros, Brevit, Carina, Malakoff and Centenario. Canadian Journal of Genetics and Cytology 10, 7-17.

Dyck PL, Samborski DL (1968b) Host-parasite interactions involving two genes for leaf rust resistance in wheat. In 'Proceedings of the Third International Wheat Genetics Symposium'. Canberra, Australia (Eds KW Finlay, KW Shepherd) pp. 245-250. (Australian Academy of Science: Canberra)

Dyck PL, Samborski DL (1970) The genetics of two alleles for leaf rust resistance at the Lr14 locus in wheat. Canadian Journal of Genetics and Cytology 12, 689-694.

Dyck PL, Samborski DL (1982) The inheritance of resistance to Puccinia recondita in a group of common wheat cultivars. Canadian Journal of Genetics and Cytology 24, 273-283.

Dyck PL, Samborski DL, Anderson RG (1966) Inheritance of adult plant-leaf rust resistance derived from the common wheat varieties Exchange and Frontana. Canadian Journal of Genetics and Cytology 8, 665-671.

FAOSTAT (2006) Core production data (online). (FAO: Rome). Available at: http://faostat.fao.org/site/340/default.aspx. Verified: July 2006.

Germán S, Caffarel JC (1999) Roya estriada de trigo. In 'Jornada de Cultivos de Invierno'. INIA La Estanzuela, Colonia, Uruguay. pp. 25-32. Serie Actividades de Difusión No. 188, La Estanzuela.

Germán S, Diaz M, Verges R, Castro M (2005) Breeding for resistance to wheat rusts in a highly favourable environment for diseases. In 'Wheat production in stressed environments: Abstracts of oral and poster presentations [of the] 7th International Wheat Conference'. Mar del Plata, Argentina. pp. 139. (Secretariat of Agriculture, Animal Husbandry, Fisheries and Food) 
Germán S, Kohli M, Chaves M, Barcellos A, Nisi J, Annone J, Madariaga R, de Viedma L (2004) Breakdown of resistance of wheat cultivars and estimated losses caused by recent changes in the leaf rust population in South America. In 'Abstracts [of the] 11 th International Cereal Rusts and Powdery Mildews Conference'. John Innes Centre, Norwich, England, UK. pp. A2.21.

Germán S, Kolmer JA (1996) Genetics of leaf rust resistance in selected Uruguayan wheat cultivars. In 'Proceedings of the 9th European and Mediterranean Cereal Rusts \& Powdery Mildews Conference'. Lunteren, The Netherlands. (Eds GHJ Kema, RE Niks, RA Daamen). Cereal Rusts and Powdery Mildews Bulletin 24, 235.

Germán SE, Abadie T, Perea C (1986) Epifitia de roya de la hoja sobre el cultivar de trigo La Paz INTA. Investigaciones Agronómicas (Montevideo) 7, 75-77.

Germán SE, Kolmer JA (1994) Virulence phenotypes of Puccinia recondita f. sp. tritici in Uruguay. Plant Disease 78, 1139-1141.

Hacke E (1986) Investigación en polvillos (o royas) del trigo realizadas en Chile en las temporadas 1982-83 a 1984-85. In 'Reunião de Especialistas em Ferrugens de Cereais de Inverno'. CNPT/EMBRAPA, Passo Fundo, RS. Diálogo No. 13. (Ed. CJ Molestina) pp. 137-152. (PROCISUR: Montevideo)

Hacke E (1990) Investigación en polvillos o royas del trigo realizada en el período 1985-1989 en Chile. In 'Reunião Técnica sobre Ferrugens. Projeto Trigo'. CNPT/EMBRAPA, Passo Fundo, RS. pp. 1-28. (PROCISUR)

Haggag MEA, Dyck PL (1973) The inheritance of leaf rust resistance in four common wheat varieties possessing genes at or near the Lr3 locus. Canadian Journal of Genetics and Cytology 15, $127-134$

Hewstone MC (1983) Mejoramiento de trigos para el sur de Chile In 'Reunião de Melhoristas de Trigo do Cone Sul', EMBRAPA-CNPT, Passo Fundo, RS. (Coord. O de S Rosa) pp. 101-109. Diálogo No. 9. (Programa Cooperativo de Pesquisa Agricola: Montevideo)

Kohli MM, Skovmand B (1997) Wheat varieties of South America. Names, parentage, pedigrees, and origins. (CIMMYT: México DF)

Kohli MM, Ulery A, Quincke M (2003) Intercambio de germoplasma regional de trigo en el Cono Sur. In 'Estrategias y Metodologías utilizadas en el Mejoramiento de Trigo: un enfoque multidisciplinario' INIA La Estanzuela, Colonia, Uruguay. (Eds MM Kohli, M Díaz de Ackermann, M Castro) pp. 230-242. (CIMMYT-INIA: Montevideo)

Kolmer JA (1996) Genetics of resistance to wheat leaf rust. Anmual Review of Phytopathology 34, 435-455. doi: 10.1146/annurev. phyto.34.1.435

Kolmer JA, Liu JQ (2001) Simple inheritance of partial resistance to leaf rust in two wheat cultivars. Plant Pathology 50, 546-551. doi: 10.1046/j.1365-3059.2001.00607.x

Kolmer JA, Long DL, Hughes ME (2004) Physiologic specialization of Puccinia triticina on wheat in the United States in 2002. Plant Disease 88, 1079-1084

Kolmer JA, Oelke LM, Liu JQ (2007) Genetics of leaf rust resistance in three Americano landrace derived wheat cultivars from Uruguay. Plant Breeding 126, 152-157.

Lewis S, Bullrich L, Suárez E (2003) Desarrollo de germoplasma premejorado de trigo para resistencia a roya mediante selección asistida por marcadores moleculares. In 'Estrategias y Metodologías utilizadas en el Mejoramiento de Trigo: un enfoque multidisciplinario'. INIA La Estanzuela, Colonia, Uruguay. (Eds MM Kohli, M Díaz de Ackermann, $\mathrm{M}$ Castro) pp. 317-318. (CIMMYT-INIA: Montevideo)

Long DL, Koimer JA (1989) A North American system of nomenclature for Puccinia recondita f.sp, tritici. Phytopathology 79, 525-529.

Luizzi DV, Gatti de DeLeón I, Cabrera N (1980) Selección por resistencia a roya de tallo (Puccinia graminis Pers. f. sp. tritici) en trigo. Investigaciones Agronómicas (Montevideo) 1, 32-35.
Madariaga R, Mellado M, Becerra V (2004). Significance of wheat yellow rust $(Y r)$ genes in Chile. In 'Abstracts [of the] 11th International Cereal Rusts and Powdery Mildews Conference'. John Innes Centre, Norwich, England, UK. p. A2.38.

McIntosh RA (1992) Close genetic linkage of genes conferring adult plant resistance to leaf rust and stripe rust of wheat. Plant Pathology 41, 523-527.

McIntosh RA, Wellings CR, Park RF (1995) 'Wheat rusts: An atlas of resistance genes.' (CSIRO: Canberra)

Rajaram S, Campos A (1974) Epidemiology of wheat rusts in the Western Hemisphere. CIMMYT Research Bulletin No. 27, México, DF.

Rajaram S, Singh RP, Torres E (1988) Current CIMMYT approaches in breeding wheat for rust resistance. In 'Breeding strategies for resistance to the rusts of wheat'. (Eds NW Simmonds, S Rajaram) pp. 101-118. (CIMMYT: México DF)

Ribeiro R (1952) Evolución varietal del trigo en el Uruguay. Archivo Fitotécnico del Uruguay (Montevideo) 5, 373-391.

Roelfs AP (1988) Resistance to leaf and stem rusts in wheat. In 'Breeding strategies for resistance to the rusts of wheat'. (Eds NW Simmonds, S Rajaram) pp. 10-22. (CIMMYT: México, DF)

Rosa Filho O (1997) Effect of the six glutenin loci on selected bread quality traits in wheat. $\mathrm{PhD}$ thesis, Oregon State University, Corvallis, OR, USA.

Rudorf G, Job MM, von Rosenstiel K (1933) Investigaciones sobre inmunidad en trigo. (Universidad Nacional de La Plata: Argentina)

Schramm W (1969) Molestias do trigo no RS. Ciência e Cultura (São Paulo) 21, 777-782.

da Silva AR (1966) Melhoramento das variedades de trigo destinadas às diferentes regiões do Brasil. Serviço de Informação Agrícola, Estudos técnicos No. 33, Rio de Janeiro.

da Silva PR (2002) Identificação e conversão de marcadores moleculares associados à resistência à ferrugem da folha em trigo. Dissertação de Mestrado, UFRGS, Porto Alegre, RS, Brasil.

Singh RP (1992) Genetic association of leaf rust resistance gene $\mathrm{Lr} 34$ with adult plant resistance to stripe rust in bread wheat. Phytopathology $\mathbf{8 2}$, 835-838.

Singh RP (1993) Resistance to leaf rust in 26 Mexican wheat cultivars. Crop Science 33, 633-637.

Singh RP, Huerta Espino J (1995) Inheritance of seedling and adult plant resistance to leaf rust in wheat cultivars Ciano 79 and Papago 86. Plant Disease 79, 35-38.

Singh RP, Huerta-Espino J, William M (2003) Resistencia durable a roya de la hoja y roya amarilla del trigo: genética y mejoramiento en el CIMMYT. In 'Estrategias y Metodologías utilizadas en el Mejoramiento de Trigo: un enfoque multidisciplinario'. INIA La Estanzuela, Colonia, Uruguay. (Eds MM Kohli, M Díaz de Ackermann, M Castro) pp. 109-118. (CIMMYT-INIA: Montevideo)

Singh RP, Rajaram S (1991) Resistance to Puccinia recondita f.sp. tritici in 50 Mexican bread wheat cultivars. Crop Science 31, $1472-1479$.

Singh RP, Rajaram S (1992) Genetics of adult-plant resistance of leaf rust in 'Frontana' and three CIMMYT wheats. Genome 35, 24-31.

Singh RP, Rajaram S (1994) Genetics of adult plant resistance to stripe rust in ten spring bread wheats. Euphytica 72, 1-7. doi: 10.1007/BF00023766

de Sousa CNA, Barcellos AL (2000) Evaluation of leaf tip necrosis in Brazilian wheat genotypes. Annual Wheat Newsletter 46, 31 .

de Sousa CNA, Barcellos AL (2001) Resultados de testes para necrose hibrida ( $L r$ l3) em populações $F_{1}$ de cruzamentos de trigo na Embrapa Trigo. EMBRAPA Trigo, Comunicado On line No. 61. Disponivel: http://www.cnpt.embrapa.br/biblio/p_co61.htm. Consultado: Agosto $2005^{*}$

Straib W (1937) Las razas fisiológicas de Puccinia glumarum en Sudamérica y su comportamiento en la infección comparado con el de las formas europeas. Archivo Fitotécnico del Uruguay (Montevideo) 2, $217-233$ 
The TT, Gupta RB, Dyck PL, Appels R, Hohmann U, McIntosh RA (1991) Characterization of stem rust resistant derivatives of wheat cultivar Amigo. Euphytica 58, 245-252. doi: 10.1007/BF00025256

Vallega J (1938) Dos nuevas selecciones de trigo de origen híbrido inmunes a Puccinia glumanum. Revista de la Facultad de Agronomia (La Plata) 22, 139-145

Vallega J (1940) Especialización fisiológica de Puccinia graminis tritici en Argentina, Chile y Uruguay. Revista Argentina de Agronomía (Buenos Aires) 7, 196-220.

Vallega J (1955) Wheat rust races in South America. Phytopathology 45, $242-245$.

Vallega J, Favret EA (1947) Royas y otros parásitos de los cereales en los valles andino-patagónicos. Revista de Investigaciones Agricolas (Buenos Aires) 1, 269-277.

Vallega J, Favret EA (1952) Las royas de los cereales en Argentina. (I Parte). IDIA (Buenos Aires) 54, 17-39.

de Viedma L, Bozzano G (1986) Las Royas del trigo en Paraguay. In 'Reunião de Especialistas em Ferrugens de Cereais de Inverno'. CNPT/EMBRAPA, Passo Fundo, RS. Diálogo No. 13. (Ed. CJ Molestina) pp. 153-164. (PROCISUR: Montevideo) de Viedma L, Kohli MM, German S (2005) Sources of adult plant resistance for leaf rust of wheat in Paraguay. In 'Wheat production in stressed environments: abstracts of oral and poster presentations [of the] 7th International Wheat Conference'. Mar del Plata, Argentina. pp. 164. (Secretariat of Agriculture, Animal Husbandry, Fisheries and Food)

Volovsky D (1945) Identificación de razas fisiológicas de Puccinia graminis tritici y $P$. triticina, algunos estudios efectuados en Chile. Agricultura Técnica 1, 70-78 [Santiago de Chile].

Volovsky D (1946) Nuevas razas fisiológicas de Puccinia triticina para Chile: notas cientificas. Agricultura Técnica 6, 67 [Santiago de Chile].

Zoldan SM, Barcellos AL (2002) Postulation of genes $(L r)$ for resistance to leaf rust in Brazilian wheat cultivars. Fitopatologia Brasileira 27, 508-516. doi: 10.1590/S0100-41582002000500012

Zoldan SM, Barcellos AL, de Sousa CNA (2000) Detecção do gene $\operatorname{Lr} 13$ de resistência à ferrugem da folha em plântulas de trigo. Fitopatologia Brasileira 25, 512-516.

Manuscript received 10 May 2006, accepted 16 October 2006 